\title{
Influence of Adding Manganese to Tris Extender on some Post-Cryopreservation Semen Attributes of Holstein Bulls
}

\author{
Sajeda Mahdi Eidan", Talal Anwer Abdulkareem, Omer Amer Abd Sultan \\ Department of Animal Resource, College of Agriculture, University of Baghdad, Baghdad, Iraq \\ Email address: \\ dr_staaa@yahoo.com (S. M. Eidan), talal200320032000@yahoo.com (T. A. Abdulkareem), omaraamer01@yahoo.com (O. A. A. Sultan)
}

\section{To cite this article:}

Sajeda Mahdi Eidan, Talal Anwer Abdulkareem, Omer Amer Abd Sultan. Influence of Adding Manganese to Tris Extender on some PostCryopreservation Semen Attributes of Holstein Bulls. International Journal of Applied Agricultural Sciences. Vol. 1, No. 2, 2015, pp. $26-30$. doi: $10.11648 /$ j.ijaas.20150102.12

\begin{abstract}
This study was conducted to explore the adding effect of manganese $\left(\mathrm{Mn}^{+2}\right)$ to Tris extender on post cooling and cryopreservation semen attributes of Holstein bulls for different periods. Seven Holstein bulls of 3.5-4.5 years old were used in this study. Pooled semen was divided into three groups. The first group was diluted with Tris only (control group, G1). While the $2^{\text {nd }}(\mathrm{G} 2)$ and $3^{\text {rd }}(\mathrm{G} 3)$ groups were added 0.7 and $0.9 \mathrm{mM} \mathrm{Mn}^{+2}$ respectively. The effect of these additions on Holstein bulls semen quality was studied during different periods (cooling at 5 Celsius, $72 \mathrm{hrs} ., 1^{\text {st }}, 2^{\text {nd }}$ and $3^{\text {rd }}$ post cryopreservation, PC). Addition of $\mathrm{Mn}^{+2}$ led to significant increases of total $\left(\times 10^{6}\right)$ plasma membrane integrity of sperms and total function sperm fraction as compared with control groups during cooling and PC periods. It can be concluded that the addition two levels of acid $\mathrm{Mn}^{+2}$ led to enhanced PC semen quality of bulls. This will in turn improved fertility rate of cows and owner's economic income.
\end{abstract}

Keywords: $\mathrm{Mn}^{+2}$, Cryopreservation, Holstein Bulls Semen

\section{Introduction}

Plasma membrane and acrosome are important sites for the changes caused by cryopreservation(associated with oxidative stress) process. Cryopreservation affects the lipid architecture of plasma membrane [1 and] and metabolism due to the high amount of polyunsaturated fatty acids (PUFAs) with significantly less cytoplasmic components containing antioxidants [2]. The PUFAs plays an important role in regulating sperm membrane fluidity and spermatogenesis [3]. Alteration of the membrane fluidity during freezing-thawing processes will cause accumulation of calcium ion which consequently impaired sperm motility and eventually endanger the sperm survival [4]. Bovine sperm themselves have only few amounts of endogenous antioxidants for the protection against reactive oxygen species (ROS) and the main antioxidant source is the seminal plasma [5 and 6]. Several ROS produced by both sperm and leukocytes contaminating the seminal fluid, adversely affect sperm motility and impair fertilizing ability [7]. Antioxidative mechanisms protect the sperm from the damage caused by free radicals [8].

Manganese is an essential ultra-trace element, needed for a variety of physiological processes ranging from the regulation of reproduction to normal brain functions [9]. The $\mathrm{M}^{+2}$ is an important cofactor of mitochondrial superoxide dismutase, an antioxidant enzyme which scavenges oxygen free radicals [10]. It inhibits LPO produced by a free radical producing system, as potent antioxidant against oxidative stress at low doses [11]. $\mathrm{Mn}^{+2}$ supplementation reduced the leakage of lipids and phospholipid sperm contents under normal and induced oxidative stress conditions [12]. $\mathrm{Mn}^{+2}$ is able to penetrate the cell easily and help sperm to maintain or recover appropriate ion balance. Thus, it suffer less from the freezing and thawing procedures [13]. Bansal et al [14] suggest the role of $\mathrm{Mn}^{+2}$ supplementation in improving the quality of bull semen by its scavenging property, through reduction of ROS production during its incubation at $37^{\circ} \mathrm{C}$ for capacitation or storage at $4^{\circ} \mathrm{C}$. Moreover, Eidan et al [15] recorded that addition of $\mathrm{Mn}^{+2}$ to Tris extender led to significant increases of total $\left(\times 10^{6}\right)$ motile spermatozoa, acrosomal integrity of sperms and normal morphology of sperms as compared with control groups at different PC periods

The previous studies did not identify the accurate concentrations of these relevant antioxidants, and contradictory results have been reported. Higher concentrations of $\mathrm{Mn}^{+2}$ may give better PC semen 
characteristics of Holstein bulls. Therefore, the objective of this study was to investigate effect of adding $\mathrm{Mn}^{+2}$ to Tris extender on some PC semen characteristics of Holstein bulls.

\section{Materials and Methods}

Seven Holstein bulls, 3.5- 4.5 years old and 550-770 kg live body weight, were trained for semen collection using artificial vagina. The experimental bulls have good health and free of disease, being under the veterinarian supervision permanently. Animals fed $4 \mathrm{~kg}$ concentrate ration/ bull /day composed of $33 \%$ wheat bran, $20 \%$ soybean, $35 \%$ barley, , $10 \%$ yellow corn, $0.5 \%$ salt $0.5 \%$ limestone, and $1 \%$ vitamins and minerals. Total crude protein and energy contents were $18 \%$ and $3323 \mathrm{kcal} / \mathrm{kg}$ respectively. Green fodder (51-61 kg / bull / day) alfalfa hay (8-9 kg/bull /day) were also introduced. Pooled semen was taken from each bull and combining together to remove the individual variations among bulls. The extender was prepared according to the method of Salamon and Maxwell [16]. Semen was divided equally to three groups. First group was considered as a control group (G1) diluted with Tris only. Manganese (Gailad Chemical Company $\backslash \mathrm{UK})$ was added to $\mathrm{G} 2(0.5 \mathrm{mM})$ and $\mathrm{G} 3$ $(1.0 \mathrm{mM})$ treatments respectively. Semen evaluation was done on each treatment following cooling $\left(5^{\circ} \mathrm{C}\right)$ and 72 hours, $1^{\text {st }}, 2^{\text {nd }}$ and $3^{\text {rd }}$ PC periods. Semen characteristics involve total plasma membrane integrity of sperms(TPMIS), total osmotic shock of sperms(TOSS) and total function sperm fraction (TFSF) in each straw $\left(20 \times 10^{6}\right.$ sperm) were determined according to Jeyendran et al [17], Zavos [18] and Johnston et al [19]. The statistical computations were performed using SAS program [20] based on completely randomized design (CRD) to study the effect of different factors on the studied characteristics. Means with significant differences were compared using Duncan multiple range test [21].

\section{Results and Discussion}

Highly significant $(\mathrm{p} \leq 0.01)$ effect of two $\mathrm{Mn}^{+2}$ levels was noticed on TPMIS among different preservation periods (cooling, $72 \mathrm{hrs} ., 1^{\text {st }}, 2^{\text {nd }}$ and $3^{\text {rd }} \mathrm{PC}$ ) as compared with control group (Table 1). Furthermore, TPMIS was significantly greater $(\mathrm{p} \leq 0.01)$ in G3 treatment $\left(14.61 \pm 0.25 \times 10^{6}\right)$ in comparison with G2 $\left(13.22 \pm 0.46 \times 10^{6}\right)$ treatment at $72 \mathrm{hrs}$. PC period. No significant differences were observed in TPMIS at different preservation periods within G1 and G2 treatments. On the other hand, G3 treatment exhibited significant $(\mathrm{p} \leq 0.05)$ differences in TPMIS $\left(14.6 \pm 0.2 \times 10^{6}\right)$ during $72 \mathrm{hrs}$. as compared with both $2^{\text {nd }}\left(13.6 \pm 0.2 \times 10^{6}\right)$ and $3^{\text {rd }}\left(13.6 \pm 0.2 \times 10^{6}\right)$ month PC (Table 1$)$.

The TOSS was decreased $(\mathrm{p} \leq 0.01)$ in G3 $\left(1.20 \pm 0.06 \times 10^{6}\right)$ and G2 $\left(1.50 \pm 0.07 \times 10^{6}\right)$ groups as compared with G1 group $\left(1.74 \pm 0.06 \times 10^{6}\right)$ at cooling. The G3 treatment exhibited lower $(\mathrm{p} \leq 0.01)$ TOSS value $\left(1.23 \pm 0.06 \times 10^{6}\right)$ in comparison with $\mathrm{Gl}\left(1.59 \pm 0.09 \times 10^{6}\right)$ at $72 \mathrm{hrs}$. PC period (Table 2). On the other hand, no significant differences were recorded between G3 $\left(1.23 \pm 0.06 \times 10^{6}\right)$ and G2 $\left(1.44 \pm 0.07 \times 10^{6}\right)$ at 72 hrs. PC period. G3 treatment exhibited lower TOSS value in comparison with both $\mathrm{G} 1$ and $\mathrm{G} 2$ at $1^{\text {st }}, 2^{\text {nd }}$ and $3^{\text {rd }} \mathrm{PC}$ periods(Table 2). No significant differences were noticed among the overall experimental periods $\left(5^{\circ} \mathrm{C}, 72 \mathrm{hrs} ., 1^{\text {st }} 2^{\text {nd }}\right.$ and $3^{\text {rd }} \mathrm{PC}$ period) within each treatment (Table 2$)$.

The G2 $\left(6.54 \pm 0.44 \times 10^{6}\right)$ and G3 $\left(7.27 \pm 0.41 \times 10^{6}\right)$ groups exhibited higher $(\mathrm{p} \leq 0.01)$ TFSF values as compared with $\mathrm{G} 1$ group $\left(3.79 \pm 0.27 \times 10^{6}\right)$ at cooling period (Table 3$)$. The $\mathrm{G} 3\left(6.37 \pm 0.33 \times 10^{6}\right)$ and $\mathrm{G} 2\left(5.65 \pm 0.38 \times 10^{6}\right)$ groups recorded highly significant differences $(\mathrm{p} \leq 0.01)$ in TFSF values as compared with G1 group $\left(2.88 \pm 0.18 \times 10^{6}\right)$ at 72 hrs. PC period (Table 3). The G2 (4.20 $\pm 0.51-4.93 \pm$ $\left.0.37 \times 10^{6}\right)$ and G3 $\left(5.09 \pm 0.32-5.56 \pm 0.29 \times 10^{6}\right)$ groups exhibited higher $(\mathrm{p} \leq 0.01)$ TFSF values as compared with G1 group $\left(2.07 \pm 0.25-2.25 \pm 0.18 \times 10^{6}\right)$ during $1^{\text {st }}, 2^{\text {nd }}$ and $3^{\text {rd }}$ PC periods (Table 3 ).

Highly significant differences $(p \leq 0.01)$ were noticed in TFSF $\left(\times 10^{6}\right)$ values between cooling and the overall PC periods within group G1 (Table 3). Within the relevant characteristic and group, no significant differences were noticed among $1^{\text {st }}, 2^{\text {nd }}$ and $3^{\text {rd }}$ month PC (Table 3$)$. On the other hand, TFSF $\left(\times 10^{6}\right)$ was greater $(p \leq 0.01)$ at cooling $(6.54 \pm 0.44)$ in comparison with $1^{\text {st }}(4.93 \pm 0.37), 2^{\text {nd }}(4.48 \pm$ $0.37)$ and $3^{\text {rd }}(4.20 \pm 0.51)$ month PC within G2 group (Table 3). Meanwhile, no significant differences were noticed among $1^{\text {st }}, 2^{\text {nd }}$ and $3^{\text {rd }}$ month PC within G2 group (Table 3 ). Cooling $(7.27 \pm 0.41), 72$ hrs. $(6.37 \pm 0.33)$ and $1^{\text {st }}(5.56 \pm 0.29)$ month PC were superior $(\mathrm{p} \leq 0.01)$ in TFSF $\left(\times 10^{6}\right)$ values as compared with those at $2^{\text {nd }}(5.12 \pm 0.37)$ and $3^{\text {rd }}(5.09 \pm 0.32)$ month PC within G3 group (Table3).

Table 1. The Effect of adding Mn+2 to Tris extender on the total plasma membrane integrity of sperms (TPMIS $\left.\times 10^{6}\right)$ at cooling and different postcryopreservation (PC) periods in Holstein bulls.

\begin{tabular}{|c|c|c|c|c|c|c|}
\hline Period Treat. & $5^{\circ} \mathrm{C}$ & 72 hrs. PC & $1^{\text {st }}$ mo. PC & $2^{\text {nd }}$ mo. PC & $3^{\text {rd }}$ mo. PC & Sig. \\
\hline G1 & $10.7 \pm 0.5 \mathrm{~B} \mathrm{a}$ & $10.8 \pm 0.5 \mathrm{C} \mathrm{a}$ & $10.2 \pm 0.6 \mathrm{~B} \mathrm{a}$ & $9.9 \pm 0.5 \mathrm{~B} \mathrm{a}$ & $9.8 \pm 0.5 \mathrm{~B} \mathrm{a}$ & ns \\
\hline $\mathrm{G} 2$ & $13.2 \pm 0.6 \mathrm{~A} \mathrm{a}$ & $13.2 \pm 0.4 \mathrm{~B} \mathrm{a}$ & $12.8 \pm 0.5 \mathrm{~A} \mathrm{a}$ & $12.8 \pm 0.5 \mathrm{~A} \mathrm{a}$ & $12.6 \pm 0.6 \mathrm{~A} \mathrm{a}$ & ns \\
\hline G3 & $14.3 \pm 0.3 \mathrm{~A} \mathrm{ab}$ & $14.6 \pm 0.2 \mathrm{~A} \mathrm{a}$ & $14.0 \pm 0.2 \mathrm{~A} \mathrm{ab}$ & $13.6 \pm 0.2 \mathrm{Ab}$ & $13.6 \pm 0.2 \mathrm{Ab}$ & $*$ \\
\hline Sig. & $* *$ & $* *$ & $* *$ & $* *$ & $* *$ & \\
\hline
\end{tabular}

Means with capital superscripts within each column indicate comparison among treatments and small superscripts within each row indicate comparison among periods within each treatment. mo.: month. Sig.: significance. ns: no significant. $* *(p \leq 0.01)$. G1: Tris extender (Control group). G2: Tris extender $+0.7 \mathrm{mM}$ $\mathrm{Mn}^{+2}$. G3: Tris extender $+0.9 \mathrm{mM} \mathrm{Mn}^{+2}$.

The Addition of two $\mathrm{Mn}^{+2}$ levels had an obvious effect $(p \leq 0.01)$ in improving TPMIS and TFSF as compared with control groups during cooling and PC periods. Some of these results were in line with Lapointe et al [13] who found that 
the addition of $0.1 \mathrm{mM} \mathrm{Mn}^{+2}$ to semen extender enhanced PC individual motility (53\%) as compared with control group $(28 \%)$. The current results also agreed with Cheema et al [22] who found that the addition of $\mathrm{Mn}^{+2}(150 \mu \mathrm{M})$ to egg-yolk- citrate extender increased PC individual motility (58.3\%) in comparison with those of control group (45\%). Similar authors found that the addition of $\mathrm{Mn}^{+2}$ to

Table 2. The Effect of adding Mn+2 to Tris extender on the total osmotic shock $\left(T O S S \times 10^{6}\right)$ at cooling and different post-cryopreservation (PC) periods in Holstein bulls.

\begin{tabular}{|c|c|c|c|c|c|c|}
\hline Period Treat. & $5^{\circ} \mathrm{C}$ & 72 hrs. PC & $1^{\text {st }} \mathrm{mo.PC}$ & $2^{\text {nd }}$ mo. PC & $3^{\text {rd }}$ mo.PC & Sig. \\
\hline G1 & $1.74 \pm 0.06 \mathrm{~A} \mathrm{a}$ & $1.59 \pm 0.09 \mathrm{~A} \mathrm{a}$ & $\begin{array}{l}1.61 \pm 0.08 \\
\mathrm{~A} \mathrm{a}\end{array}$ & $\begin{array}{l}1.60 \pm 0.08 \\
\mathrm{Aa}\end{array}$ & $\begin{array}{l}1.69 \pm 0.08 \\
\mathrm{~A} \mathrm{a}\end{array}$ & ns \\
\hline G2 & $\begin{array}{l}1.50 \pm 0.07 \\
\mathrm{~B} \mathrm{a}\end{array}$ & $\begin{array}{l}1.44 \pm 0.07 \\
\mathrm{AB} \mathrm{a}\end{array}$ & $\begin{array}{l}1.53 \pm 0.07 \\
\mathrm{~A} \mathrm{a}\end{array}$ & $\begin{array}{l}1.72 \pm 0.15 \\
\mathrm{~A} \mathrm{a}\end{array}$ & $\begin{array}{l}1.54 \pm 0.06 \\
\mathrm{~A} \mathrm{a}\end{array}$ & ns \\
\hline G3 & $\begin{array}{l}1.20 \pm 0.06 \\
\mathrm{C} \mathrm{a}\end{array}$ & $\begin{array}{l}1.23 \pm 0.06 \\
\mathrm{~B} \mathrm{a}\end{array}$ & $\begin{array}{l}1.23 \pm 0.09 \\
\mathrm{~B} \mathrm{a}\end{array}$ & $\begin{array}{l}1.20 \pm 0.07 \\
\mathrm{~B} \mathrm{a}\end{array}$ & $\begin{array}{l}1.29 \pm 0.09 \\
\mathrm{~B} \mathrm{a}\end{array}$ & ns \\
\hline
\end{tabular}

Means with capital superscripts within each column indicate comparison among treatments and small superscripts within each row indicate comparison among periods within each treatment. mo.: month. Sig.: significance. ns: No significant. $* *(p \leq 0.01)$. G1: Tris extender (Control group). G2: Tris extender with $0.7 \mathrm{mM}$ $\mathrm{Mn}^{+2}$. G3: Tris extender with $0.9 \mathrm{mM} \mathrm{Mn}^{+2}$.

Table 3. Effect of adding $\mathrm{Mn}^{+2}$ to Tris extender on the Total function sperm fraction (TFSF) $\left(\times 10^{6}\right)$ at cooling and different post-cryopreservation (PC) periods in Holstein bulls.

\begin{tabular}{|c|c|c|c|c|c|c|}
\hline PeriodTreat. & $5^{\circ} \mathrm{C}$ & 72 hrs. PC & $1^{\text {st }}$ mo. PC & $2^{\text {nd }}$ mo. PC & $3^{\text {rd }}$ mo. PC & Sig. \\
\hline \multirow{2}{*}{ G1 } & $3.79 \pm 0.27$ & $2.88 \pm 0.18$ & $2.25 \pm 0.18$ & $2.15 \pm 0.23$ & $2.07 \pm 0.25$ & \multirow[t]{2}{*}{$* *$} \\
\hline & $\mathrm{B}$ a & $\mathrm{B} \mathrm{b}$ & $\mathrm{Bcb}$ & $\mathrm{B} \mathrm{c}$ & $\mathrm{B} \mathrm{c}$ & \\
\hline \multirow{2}{*}{$\mathrm{G} 2$} & $6.54 \pm 0.44$ & $5.65 \pm 0.38$ & $4.93 \pm 0.37$ & $4.48 \pm 0.37$ & $4.20 \pm 0.51$ & \multirow[t]{2}{*}{$* *$} \\
\hline & $\mathrm{A} \mathrm{a}$ & $\mathrm{A} a b$ & $\mathrm{Abc}$ & $\mathrm{A} b c$ & $\mathrm{Ac}$ & \\
\hline \multirow{2}{*}{ G3 } & $7.27 \pm 0.41$ & $6.37 \pm 0.33$ & $5.56 \pm 0.29$ & $5.12 \pm 0.37$ & $5.09 \pm 0.32$ & \multirow[t]{2}{*}{$* *$} \\
\hline & $\begin{array}{l}\mathrm{A} \mathrm{a} \\
* *\end{array}$ & $\begin{array}{l}\mathrm{A} \mathrm{ab} \\
* *\end{array}$ & $\begin{array}{l}\text { Aab } \\
* *\end{array}$ & $\begin{array}{l}\mathrm{Ac} \\
* *\end{array}$ & $\begin{array}{l}\mathrm{Ac} \\
* *\end{array}$ & \\
\hline
\end{tabular}

Means with capital superscripts within each column indicate comparison among treatments and small superscripts within each row indicate comparison among periods within each treatment. mo.: month. Sig.: significance. ns: No significant. ${ }^{*}(\mathrm{p} \leq 0.01)$. G1: Tris extender (Control group). G2: Tris extender with $0.7 \mathrm{mM}$ $\mathrm{Mn}+2$. G3: Tris extender with $0.9 \mathrm{mM} \mathrm{Mn}+2$.

Tris extender improved PC plasma membrane integrity $(30.1 \%)$ in comparison with the control group (19.7\%). Moreover, these data were agreed with those of Eidan et al "in press" [23] and Eidan and Sultan "unpublished" [24] who observed that addition of 0.7 and $0.9 \mathrm{mM}$ of $\mathrm{Mn}^{+2}$ to Tris extender have improved individual motility, live sperm, sperm plasma membrane integrity, freezing ability percentages and decreased Malondialdehyde (MDA) concentrations at cooling and post-cryopreservation of semen.

However, excluding data of Eidan and Sultan "unpublished" [24], the current $\mathrm{Mn}^{+2}$ concentrations are higher than those pointed out in the previous studies. Many preliminary trials were conducted to select these concentrations based on their significant effects. It is worthy to mention that the concentrations used by the previous studies had negative effects on PC semen characteristics when used in the preliminary trials. Therefore, it is the first study that describes the effect of high $\mathrm{Mn}^{+2}$ concentrations ( 0.7 and $0.9 \mathrm{mM})$ as added to Tris extender on postcryopreservation semen quality in Holstein bulls. Manganese is an important cofactor of mitochondrial superoxide dismutase antioxidant enzyme which scavenges oxygen free radicals [25 and 26]. Manganese may stimulate the enzymes of glutathione cycle and affect the total thiols, glutathione reduced and glutathione oxidized contents in bull and human spermatozoa [12 and 27]. It acts as a potent antioxidant in protection against OS [24 and 28]. Currently, $\mathrm{Mn}^{+2}$ enhanced
TFSF may be return to stimulates the activity of sperm adenylate cyclase enzyme to maximum extent [29]. Manganese is a potent stimulator of adenylate cyclase activity in the sperm cells, and cyclic adenosine monophosphate (cAMP) concentrations are correlated with the cell motility [13]. Mann and Mann [30] and Eddy and O'Brien [31] have described that energy transduction within sperm tail, made possible by the molecular diffusion of mitochondrial adenosine triphosphate (ATP) along the flagellum for rhythmic flagellar movements. This energy, according to these workers is generated along the flagellum by a mechanic-chemical process coupled to enzymatic dephosphorylation of ATP. However, this ATP dephosphorylation is not entirely irreversible. Some of the dephosphorylated ATP can be resynthesized as a result of axonemal adenylate kinase activity. Addition of $\mathrm{Mn}^{+2}$ to Tris extender enhanced total plasma membrane integrity and total function of sperm fraction through chain-breaking antioxidant as it is able to quench peroxyl radicals and decreasing the OS [ 24, 25 and 27]. It decreases the production of thiobarbituric acid reactive substances [24 and 28]. High intracellular manganese provides protection against oxidative damage through unknown pathways [32]. The efficacy of manganese as an antioxidant has been drastically reduced in cells with hyper accumulates phosphate [32]. It is well known, that $\mathrm{Mn}^{+2}$ is a potent inhibitor of LPO in a variety of systems, while it also exerts a superoxide radical 
scavenging action, which may account for the inhibition of LPO [24]. Some studies proposed that $\mathrm{Mn}^{+2}$ might forming a complex with unsaturated lipids making them more resistant to attack by peroxides[33]. $\mathrm{Mn}^{+2}$ inhibits the free radical chain which follows the formation of hydro peroxides and formation of malondialdehyde consequently[24]. $\mathrm{Mn}^{+2}$ is able to form complexes with $\mathrm{O}^{-\bullet}$ and $\mathrm{OH}^{-}$giving rise to complexes like $\mathrm{MnO}_{2}^{+2}$ and $\mathrm{Mn}(\mathrm{OH})^{+2}$. It has been reported that $\mathrm{Mn}^{+2}$ is able to scavenge the superoxide anion. The interaction of $\mathrm{Mn}^{+2}$ with the reported free radical species supports the hypothesis of general antioxidant action that might occur through the reduction of lipid free radicals making them unable to carry on the process of LPO [24 and 33]. $\mathrm{Mn}^{+2}$ has also proved to be the best antioxidant in reducing the ferrous ascorbate-induced LPO in bull spermatozoa [34]. Manganese has beneficial influences on sperm survival during capacitation and acrosome reaction [12 and 15]. The manganese stabilizes the plasma membrane, thereby maintaining the membrane integrity and viability [15, 24 and 35].

In conclusion, addition of $\mathrm{Mn}^{+2}$ to Tris extender inhibits lipid peroxidation, and thus improving the total sperm membrane integrity, total function sperm fraction and the remaining semen characteristic at cooling and PC periods. This will certainly lead to enhance fertility of artificiallyinseminated cows. The minimum sperm number necessary to obtain acceptable fertility rates is still a great challenge for the bovine artificial insemination industry. One of the alternatives to increase the efficiency of this technology for single and multiple ovulations is the increase total sperm membrane integrity, total function sperm fraction per insemination dose post-cryopreservation. This strategy could be especially interesting when associated with protocols for estrus synchronization or fixed-time artificial insemination, resulting in higher pregnancy per insemination and, consequently, higher economic return.

\section{Acknowledgments}

The authors are grateful to Mr. Faris F. Ibrahim, Director of Artificial Insemination Center, Ministry of Agriculture and his staff members for their great assistance. The technical assistance of Mr. Omer H. Al-Zaidy and Mr. Omer A. Mohammed was also acknowledged.

\section{References}

[1] A. Kumaresan, M.R. Ansari, and A. Garg, Modulation of postthaw sperm functions with oviductal proteins in buffaloes. Anim. Reprod. Sci. 2006,90: 73-84.

[2] S. Andrabi. Fundamental principles of cryopreservation of Bos taurus and Bos indicus bull spermatozoa. Mini review. Int. J. Agri. and Biol., 2007. 9:367-369.

[3] A. Ollero, R.D. Powers, and J. G. Alvarez, Variation of docosahexaenoic acid content in subsets of human spermatozoa at different stages of maturation: Implications for sperm lipoperoxidative damage. Mol. Reprod. Dev., 2000, 55: 326-334.

[4] K. Schuh, E.J. Cartwright, E. Jankevics, K. Bundschu, J. Liebermann, J. C. Williams, A. L. Armesilla, M. Emerson, D. Oceandy, K. P. Knobeloch and L. Neyses, Plasma membrane $\mathrm{Ca}+2$ ATPase 4 is required for sperm motility and male fertility. J. Biol. Chem., 2004, 279: 28220-28226.

[5] J.F. Bilodeau, S. Chatterjee, M. A. Sired and C. Gagnon, Levels of antioxidant defenses are decreased in bovine spermatozoa after a cycle of freezing and thawing. Mol. Reprod. Dev., 2000,55:282-288.

[6] S. M. Eidan, O. H. Al-Zaidi, F.F. Ibrahim, B. A. R. Al-Timimi, W. Y. Lateef, Effect of adding catalase and glutathione reduce to Tris extender on freezing ability of Holstein bulls following different cryopreservation periods. 2015. Iraqi J. Vet. Med., $39.1 \mathrm{n}$ press.

[7] M. Fraczek, P. Szumala-Kakola, Jedrzejezak, M. Kamieniczna, and M. Kurpisz, Bacteria trigger oxygen radical release and sperm lipid peroxidation in in vitro model of semen inflammation. Fertil. Steril., 2007, 88: 1076-1085.

[8] J. M. Gallardo, Evaluation of antioxidant system in normal semen. Rev. Invest. Clin., 2007, 59: 42-47.

[9] Y. G. Aboua, S. S. Du Plessis, P. Reichgelt, and W. Brooks, The in vitro effects of superoxide some commercially available antioxidants and red palm oil on sperm motility. Asian J. Androl., 2009, 11: 695-702.

[10] L. A. Macmillan-Crow, and D. L. Cruthirds, Manganese superoxide dismutase in disease. Free Rad. Res., 2001,34:32536.

[11] L. Campanella, T. Gatta and O. Ravera, Relationship between antioxidant capacity and manganese accumulation in the soft tissues of two freshwater molluscs: Unio pictorum mancus (Lamellibranchia, Unionidae) and Viviparous ater (Gastropoda, Prosobranchia). J. Limnol., 2005, 64:153-8.

[12] A. K. Bansal, Effects of antioxidants on crossbred cattle bull spermatozoa under oxidative stress. 2006, Ph. D Thesis, Punjab Agric. Univ., Ludhiana, India.

[13] S. Lapointe, I. Ahmad and M. M. Buhr, Modulation of post thaw motility, survival, calcium uptake, and fertility of bovine sperm by magnesium and manganese. J. Dairy Sci., 1996, 12: 2163-2169.

[14] A.K. Bansal, R. S. Cheema, and V. K, Gandotra. 2011. Antioxidant effect of $\mathrm{Mn} 2+$ on capacitation and acrosome reaction of fresh and chilled cattle bull semen. Vet. Sci. Dev., 1: 69-72.

[15] S. M. Eidan, T.A. Abdulkareem, and O.A. A. Sultan, Effect of adding manganese to Tris extender on some postcryopreservation semen characteristics of Holstein bulls. June 3rd - 6th 2015. [7th Balkan Scientific Animal Science Conference, BALNIMALCON. Sarajevo].

[16] S. Salamon, and W. M. C. Maxwell, Storage of ram semen .Anim. Reprod. Sci., 2000, 62: 77-111.

[17] R.S. Jeyendran, H. H. Van der Ven, M. Perez-Pelaez, B.G. Crab and L.J.D. Zaneveld, Development of an assay to assess the functional integrity of the human sperm membrane and its relationship to the other semen characteristics. J. Reprod .Fertile., 1984, 70:219-225. 
[18] P.M. Zavos, Hypoosmotic swelling test (HOS)/functional integrity of sperm membrane. J Ass. Reprod. Technol. Androl., 1990, 2:215-216.

[19] R. C. Johnston, G.N. Clarke, D. Yi Liu, and H. W. Gordon Baker, Assessment of the sperm quality analyzer. Fertile. Sterile., 1995, 63:1071-1076.

[20] SAS. SAS ISTAT User's Guide for Personal Computers. Release 9.1 SAS Institute Inc., Cary, N. C., USA. 2010.

[21] D. B. Duncan, Multiple range and multiple F. Tests. Biometrics., 1955, 11:1-42.

[22] R.S. Cheema, A. K. Bansal and G. S. Bilaspuri, Manganese provides antioxidant protection for sperm cryopreservation that may offer new consideration for clinical fertility. Oxidative Medicine and Cellular Longevity, 2009, 2:152-159.

[23] S. M. Eidan, and O.A. A. Sultan, Ibrahim, F. F., Hurish, K. F and Naseer, H. H. 2015. Effect of adding co-enzymes ( $\alpha$-lipoic acid and Q10) and manganese on post-cryopreservation semen quality characteristics of Holstein bulls. Iraqi J. Vet. Med., $39.1 \mathrm{n}$ press.

[24] S. M. Eidan, and O.A. A. Sultan, Effect of adding manganese on post-cryopreservation semen quality characteristics of Holstein bulls. unpublished.

[25] M. Coassin, F. Ursini, and A. Bindoli, Antioxidant effect of manganese. Arch. Biochem. Biophys., 1992, 299: 330-333.

[26] J. D. Aguirre, and V. C. Culotta, Battles with iron: Manganese in oxidative stress protection. J. Biol. Chem., 2012, 287:13541-13548.
[27] A. K. Bansal, and R. J. K. Anand, Cooperative functions of manganese and thiol redox system against oxidative stress in human spermatozoa. J. Hum. Reprod. Sci., 2009, 2:75-79.

[28] A. K. Bansal, Manganese: A potent antioxidant in semen. I. J. A. S., 2013, 3: 217-221.

[29] T. Braun, The effect of divalent cations on bovine spermatozoa Adenylate cyclase activity. J. Cycl. Nucleo. Res., 1975,1: 271-281.

[30] T. Mann, and C. L. Mann, Male Reproductive Function and Semen. Springer Verlag, New York. 1981,pp.269-336.

[31] E. M. Eddy, and D. A. O'Brien, The spermatozoon. In: The Physiology of Reproduction. E. Knobil and J. D. Neil (Eds.), Raven Press, New York. 1994, pp. 29-78.

[32] A. R. Reddi, L. T. Jensen, A. Naranuntarat, L. Rosenfeld, E. Leung, R. Shah, and V. C. Culotta, The overlapping roles of manganese and $\mathrm{Cu} \backslash \mathrm{Zn}$ SOD in oxidative stress protection. Free Radic. Biol. Med., 2009, 46: 154-162.

[33] L. Cavallini, M. Valente, and A. Bindoli, On the mechanism of inhibition of lipid peroxidation by manganese. Inorg. Chim. Act., 1984, 91: 117-120.

[34] A. K. Bansal, and G. S. Bilaspuri, Mn2+: a potent antioxidant and stimulator of sperm capacitation and acrosome reaction in crossbred cattle bulls. Archiv fur Tierzucht, 2008, 51:149-156.

[35] G.S. Bilaspuri, and A.K. Bansal, Mn2+: A potent antioxidant and stimulator of sperm capacitation and acrosome reaction in crossbred cattle bulls. Arch. Tierz., 2008, 51: 149-158. 